\title{
商業施設立地の沿道化・沿道遠隔化過程に関する研究 A STUDY ON THE PROCESS FOR TENDENCY OF LOCATING WITH COMMERCIAL FACILITIES BY THE MAIN ROADSIDE, AND FOR LOCATING AT REMOTE PLACE FROM CORE OF THE CITIES
}

\author{
角谷弘喜*, 安藤元夫** \\ Hiroki KAKUTANI and Motoo ANDO
}

\begin{abstract}
The purpose of this study is to make clear the structure with location of commercial facilities, through the analysis with phenomena in areas of southwest HIROSHIMA prefecture, and to verify the hypothesis what is the process of tendency to locate along the routes and in the remote place. The above phenomena became clear as following two points. (1) It is in progress synthetically that the tendency to locate along the routes with commercial facilities. (2) The tendency for location in the remote place with commercial facilities is in progress, similarly. This tendency is conspicuous about the category of business which located recently, and at the ROUTE-2,54 in HIROSHIMA city, in spatial aspect.
\end{abstract}

Keywords : tendency of locating by the roadside, tendency to locate in remote place, commercial facilities, location, category of business, motorization

沿道化，遠隔化，商業施設，立地，業種，モータリゼーション

\section{1.はじめに}

消費者への物品供給やサービスを目的とする商業・業 務施設（以下「商業施設」または「施設」と略記する） の立地形態が, モータリゼーションの進行や生活様式の 変化などに呼応して大きく変容してきている。

商業施設の近年の立地動向には；大きな二つの特徴が みられる。そのひとつは,「沿道（立地）化」である。 すなわち, 商業施設が主要道路 ${ }^{\dagger}$ の沿線を指向しながら 立地する現象である。わが国でモータリゼーションが進 行しはじめた昭和 40 年代初期には，沿道を目指して立 地する施設の種類は，ガソリンスタンドなど一部の業種 にかぎられていた。しかし，昭和 50 年代ころから沿道 化は顕著になり，近年では，パチンコ店や書店，レスト ランといった，従来都心（立地）型とみられていたいく つかの業種も沿道化の傾向をみせるようになってきた。 それとともに，上り立地が郊外化，遠隔化する傾向も現 われてきた2)。モータリゼーションの進行が今後もつづ くとすれば，ガソリンスタンドなどのあとを追う形でこ のほかの業種も沿道化・遠隔化していく可能性は小さく ないと思われる。
一方こうした主要国道の沿線や遠隔地を目指した施 設の動きに対応するような形で生起する今ひとつの現象

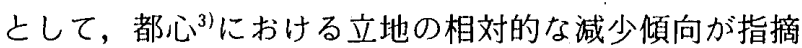
できる。すなわち, 沿道化や遠隔化が進行する結果, 都 市の中心部において停滞ないし衰退化がかなり必然性を もって起きてくるのではないかという認識である4”。

ところで, 本論で問題にする沿道化や遠隔化といった 施設の立地構造には，モータリゼーションの進行ととも に，都市計画法や大店法などの立地制限法もつよく影響 している。つまり，これらの法律は元々集積地における 過集積を避けるという目的をもち，その方向で作用して きた。集積地での立地ができない反動として沿道や遠隔 地が二次的三次的に指向されてきたのである。

本研究は，従来都心に立地してきた業種が新たに沿道 化してきている状況に加え，それらが遠隔化していると いう外的条件の変化，ならびに施設がもつ内的条件の変 化を合わせて明らかにする。これによって施設の沿道立 地に関してよりよい方向を探ることを目的としている。 なお，本研究は次の 2 点を動機とし，同時にこれは研究 をすすめる上の基本的な仮説である。一点は，(1)モータ
* 近畿大学工学部建築学科 講師

** 近畿大学理工学部建築学科 教授. 工博
Lecturer, Dept. of Architecture, Faculty of Engineering, Univ. of Kinki

Prof., Dept. of Architecture, Faculty of Science and Engineering, Univ. of Kinki, Dr. Eng. 
リゼーションが進行することによって，施設が沿道化・ 遠隔化してきたこと，つまり，モータリゼーションに影 響されて施設の立地変化が二次的に生起してきたこと， である。さらに，(2)このような現象が進行し，車対応型 の都市構造が出現することになると，交通弱者 ${ }^{5}$ が対応 しきれなくなり，施設の利用という面から問題が生じて くるのではないか, という懸念である。

以上のような動機・仮説に照らして，本稿ではとくに 次の 2 点について検討を行う。第 1 点は上記の $2 つ の$ 現 象のうち，沿道化および遠隔化を，施設の立地動向およ び業種個々の展開過程の分析を通して実証的に明らかに することで，これが本研究の主目的である。第 2 点目は, そうした外的条件の変化に伴って起きている店舗の大型 化や, 長時間営業・無休化といった内的条件の変化に着 目してその動向を描きだすことである。

なお，本研究で採り上げた「沿道化」や「遠隔化」を キーワードにしてすすめた最近の研究として，日本不動 産鑑定協会近畿会の著書(6) 石黒・小坂らの研究”があ る。前者は, 郊外ロードサイドにおける施設立地動向の 歴史的な変遷および最近の動向をふまえて, 将来の郊外 ロードサイドの方向を論じている。地価や地代に注目し て分析をすすめている点が特徴である。後者は「沿道環 境整備のための課題を整理する」という目的で行われた もので東京郊外における事例研究である。本稿はこれら の研究による知見を参照するとともに，新たに次の点に 留意した。すなわち，(1)沿道化・遠隔化という二つの現 象を既存統計資料とケーススタディとによって明らかに するが，沿道化については各「市・町」の全施設に対す る「主要国道」および「主要道路」沿線立地施設の比を 見ることによって検証する。遠隔化については都心から の距離と時間を基軸に，施設の立地変化をみる。このた め, 可能なかぎり広い区域（主要国道延長で約 $250 \mathrm{~km}$ におよぶ）を調査の範囲に設定している。(2)業種によっ て沿道化や遠隔化の傾向は異なる。全体の動向分析につ

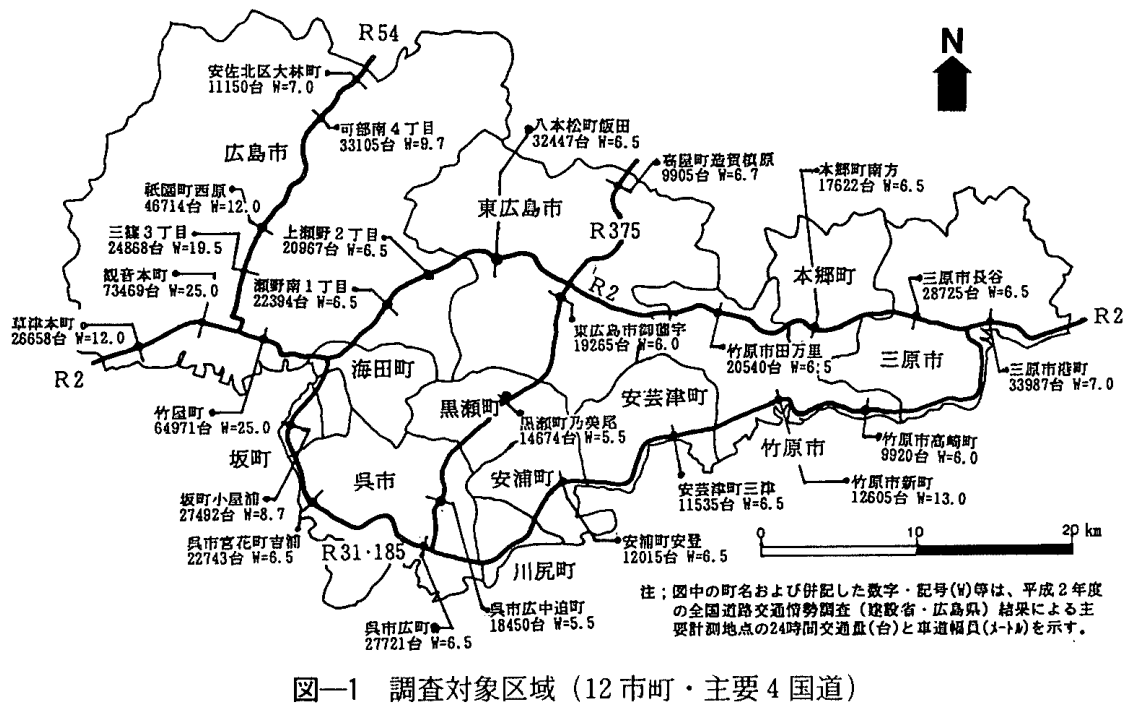

づいて，業種別に沿道化，遠隔化を分析する。なお，業 種別沿道化の違いは特定の型として取り出せる。

\section{2. 調査の概要}

\section{1 調查方法}

本研究の目的に沿って, 調査の対象区域を広島県西南 部の大・中・小都市を含む 5 市 7 町とし，その区域内を 通る主要な道路を 2 種類に分けた。ひとつは，対象区域 全体を貫いている 4 本の主要国道（2号，54 号，31・ 185 号，375 号) 8 である(図一1)。他のひとつは，これ ら 4 主要国道以外の国道や県道・市道を含む「主要道 路 $ل^{9)}$ である。調査はまず, 前者の 4 国道の沿線に立地 する商業施設 ${ }^{100} に$ に対して 2 種類の調査を行った。ひとつ は，4国道全長にわたる商業施設の立地動向をつかむた めに，すべての沿道立地施設（7 747 件）に対して行っ たヒアリングおよび観察調查である。この調查により開 業年のほか業種，建物階数などを把握した。他のひとつ は, 休日数, 営業時間, 駐車場, 立地理由などの営業内 容をつかむために，全施設の $20 \%$ に対して行ったヒア リング調查である。後者の調查では対象 773 件"1)に対し 有効回答 353 件 $(45.7 \%)$ を得た。調查の期間はとも に平成 2 年 11〜12 月である。なお，ヒアリング・観察 調査を行うために基礎資料として最新版の住宅地図（ゼ ンリンおよび中国地図出版発行）を用いた。さらに「主 要道路」沿線の立地施設の算定には, 注 13）に記載し た住宅地図などを利用した。道路の長さは，管理者であ る建設省中国地建亡広島県土木建築部道路維持課への聞 き取りによるほか各市町で作成している地図（縮尺 $1 / 1$ 万〜 1/5万）を用いてキルビメーターで測定した。この ほかにいくつかの統計資料を利用している。ひとつは, 調查対象各市町について人口と商業の動向を概観するた めに使用した国勢調查報告（昭和 55 年，平成 2 年) ${ }^{123}$ および商業統計調査報告 (昭和 54 年と 63 年版) である。 このほか「沿道化」の検証のために事業所統計調査報告 （昭和 $50,56,61$ 年の広島県版）を 利用した。

\section{2 調查対象市町の人口・商店数 の推移}

沿道化・沿道遠隔化の分析に先 立って対象 12 市町の人口と商店数 （卸売業・小売業・一般飲食とその 合計）の動向を概観する。最近 10 年間の各增娍をみたものが表一1で ある。県全体について，人口は 4.0 $\%$ 増加した。商店の中では卸売業 が $10 \%$ 以上増加したが，小壳業と 一般飲食の 2 業種が減少したため, 商店数の合計は微增（156 店增加） 
表一1 人口と商店数の増加率（\%）

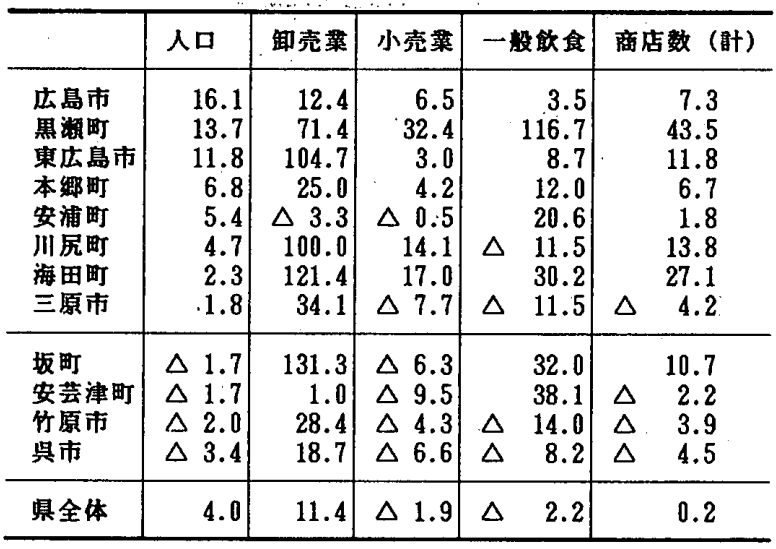

注：人口は昭和 $55 \sim 65$ 年、施設は昭和 $54 \sim 63$ 年、 $\Delta$ は娍少

となっている。

12 市町の内, 広島市を含む 5 市町が全指標とも増加, 他の 7 市町はいずれかの指標が娍少した。後者の内. 4 市 町は人口と商店数のどちらかが減少し, その内の 3 市町 は両指標ともに減少している。商店数の主要な部分を占 める小売業は 6 市町が減少し, 一般飲食とともに減少傾 向がつよい。以上にみられる人口と商店数の動向は, 他 方で,両指標がかなり連動していることも示唆している。
両者の関係は「人口」ととりわけ「小売業」との間に顕 著である。すなわち，人口が娍少した 4 市町はすべて小 売業が減少し，人口が増えても増加率が低い.(2市町) と小売業が減少している。このように, 同じ商店でも卸 売業などに比べて末端消費者との関係がつよい「小売業」 の方が，人口の増減とよりかかわっている。

このように人口と商店数は, 各市町が個別に変化する 一方，地理（位置）的には一定のま亡まりがある。つま り，国道 2 号につらなる広島，海田，東広島，本郷なよ゙ の各市町（三原を除いて）は，人口，商店数ともに増加 してきたのに対して, 呉線の $31 \cdot 185$ 号につらなる呉, 安芸津, 竹原の 3 市町は人口, 商店数ともに減少してい る（坂町は人口と小売業が減少）。このように，人口と 商店数の増娍傾向は, 東西に走る 2 本の国道につらなる 各市町において，対比的に表れている。なお，主要 4 国 道の総延長は約 $248 \mathrm{~km}$ であり; 東西・南北両方向に各 2 本がほぼ平行して走っている。いずれも広域的な都市 間連絡道路としての機能をつよくもつと同時に，各市の 中心を通り市街地の骨格を形成する主要な道路でもあ る。このうち 2 号は, 国土幹線の一部を担うもので, 他 の 3 国道と比べてより重要性が高い。
表一2 12 市町の主要国道沿道化率の推移と主要道路沿道化率

\begin{tabular}{|c|c|c|c|c|c|c|c|}
\hline \multirow{2}{*}{ 棜(国道) } & \multirow{2}{*}{$\begin{array}{c}\text { 昭和50年 } \\
\text { (主案国道) }\end{array}$} & \multirow{2}{*}{$\begin{array}{c}\text { 昭和56年 } \\
\text { (主要鲔) }\end{array}$} & \multirow{2}{*}{$\begin{array}{c}\text { 昭和61年 } \\
\text { (境酭) }\end{array}$} & \multicolumn{3}{|c|}{ 平成 2 年 } & \multirow{2}{*}{$\begin{array}{l}\text { 主要道路 } \\
\text { の本数 ( } \\
\text { 長さ·km) }\end{array}$} \\
\hline & & & & 主要国道 & 主要道路 & 計 (一解道化事) & \\
\hline 広島市(2、 & $\begin{array}{c}3.49 \\
(100.0)\end{array}$ & $\begin{array}{c}4.49 \\
(128.9)\end{array}$ & $\begin{array}{c}5.46 \\
(156.4)\end{array}$ & $\begin{array}{c}6.41 \\
(183.7)\end{array}$ & $\begin{array}{r}18.40 \\
9258\end{array}$ & $\begin{array}{l}24.81 \\
12483\end{array}$ & $17(116)$ \\
\hline $\begin{array}{l}\text { 题市 }(31 \cdot 18 \\
5,375 \text { 号 })\end{array}$ & $\begin{array}{c}6.73 \\
(100.0)\end{array}$ & $\begin{array}{c}7.58 \\
(112.6)\end{array}$ & $\begin{array}{c}9.39 \\
(139.5)\end{array}$ & $\begin{array}{c}11.68 \\
.(173.6)\end{array}$ & $\begin{array}{r}9.46 \\
942\end{array}$ & $\begin{array}{r}21.14 \\
2105\end{array}$ & $8(66)$ \\
\hline $\begin{array}{l}\text { 仡原市(2,3 } \\
1 \cdot 185 \text { 号) }\end{array}$ & $\begin{array}{c}9.18 \\
(100.0)\end{array}$ & $\begin{array}{c}10.99 \\
(119.7)\end{array}$ & $\begin{array}{c}12.73 \\
(138.7)\end{array}$ & $\begin{array}{l}14.91 \\
(162.4)\end{array}$ & $\begin{array}{r}14.79 \\
241\end{array}$ & $\begin{array}{r}29.69 \\
484\end{array}$ & $6(34)$ \\
\hline$\underset{1.185 \text { 原市 }}{(2.3}$ & $\begin{array}{c}5.11 \\
(100.0)\end{array}$ & $\begin{array}{c}6.01 \\
(117.6)\end{array}$ & $\begin{array}{c}7.57 \\
(148.1)\end{array}$ & $\begin{array}{c}8.79 \\
(172.0)\end{array}$ & $\begin{array}{r}8.52 \\
322\end{array}$ & $\begin{array}{r}17.31 \\
654\end{array}$ & $3(28)$ \\
\hline $\begin{array}{l}\text { 東広島市(2 } \\
\text { 、375号) }\end{array}$ & $\begin{array}{c}15.16 \\
(100.0)\end{array}$ & $\begin{array}{l}17.86 \\
(117.8)\end{array}$ & $\begin{array}{c}20.21 \\
(133.3)\end{array}$ & $\begin{array}{c}21.63 \\
(142.7)\end{array}$ & $\begin{array}{r}28.40 \\
865\end{array}$ & $\begin{array}{r}50.03 \\
1524\end{array}$ & $14(116)$ \\
\hline $\begin{array}{l}\text { 海田町(2、3 } \\
1 \cdot 185 \text { 号) }\end{array}$ & $\begin{array}{c}4.47 \\
(100.0)\end{array}$ & $\begin{array}{r}4.84 \\
(108.3)\end{array}$ & $\begin{array}{c}6.48 \\
(145.0)\end{array}$ & $\begin{array}{c}7.86 \\
(175.8)\end{array}$ & $\begin{array}{r}17.31 \\
196\end{array}$ & $\begin{array}{r}25.18 \\
285\end{array}$ & $3(3)$ \\
\hline $\begin{array}{l}\text { 坂 町(31. } \\
\text { 185号) }\end{array}$ & $\begin{array}{c}6.33 \\
(100.0)\end{array}$ & $\begin{array}{c}8.73 \\
(137.9)\end{array}$ & $\begin{array}{c}8.85 \\
(139.8)\end{array}$ & $\begin{array}{c}9.51 \\
(150.2)\end{array}$ & $\begin{array}{r}0.00 \\
0\end{array}$ & $\begin{array}{r}9.51 \\
41\end{array}$ & $0(00)$ \\
\hline 墨) & $\begin{array}{c}29.46 \\
(100.0)\end{array}$ & $\begin{array}{l}26.42 \\
(89.7)\end{array}$ & $\begin{array}{l}28.41 \\
(96.4)\end{array}$ & $\begin{array}{c}30.41 \\
(103.2)\end{array}$ & $\begin{array}{r}25.54 \\
131\end{array}$ & $\begin{array}{r}55.95 \\
287\end{array}$ & $4(22)$ \\
\hline 本郷町(2号) & $\begin{array}{c}7.33 \\
(100.0)\end{array}$ & $\begin{array}{c}9.26 \\
(126.3)\end{array}$ & $\begin{array}{c}10.68 \\
(145.7)\end{array}$ & $\begin{array}{c}12.36 \\
(168.6)\end{array}$ & $\begin{array}{r}33.15 \\
118\end{array}$ & $\begin{array}{r}45.51 \\
162\end{array}$ & $5(31)$ \\
\hline $\begin{array}{l}\text { 安芸津町 (3 } \\
1 \cdot 185 \text { 号) }\end{array}$ & $\begin{array}{l}14.81 \\
(100.0)\end{array}$ & $\begin{array}{c}19.60 \\
(132.3)\end{array}$ & $\begin{array}{c}26.17 \\
(176.7)\end{array}$ & $\begin{array}{c}29.07 \\
(196.3)\end{array}$ & $\begin{array}{r}30.74 \\
166\end{array}$ & $\begin{array}{r}59.81 \\
323\end{array}$ & $4(17)$ \\
\hline $\begin{array}{l}\text { 安浦叮 }(31 \cdot \\
\text { 185方) }\end{array}$ & $\begin{array}{c}17.91 \\
(100: 0)\end{array}$ & $\begin{array}{c}18.89 \\
(105.5)\end{array}$ & $\begin{array}{c}26.74 \\
(149.3)\end{array}$ & $\begin{array}{c}32.95 \\
(184.0)\end{array}$ & $\begin{array}{r}15.78 \\
68\end{array}$ & $\begin{array}{r}48.72 \\
210\end{array}$ & $2(8)$ \\
\hline $\begin{array}{l}\text { 川厐町(31. } \\
185 \text { 号) }\end{array}$ & $\begin{array}{c}11.29 \\
(100.0)\end{array}$ & $\begin{array}{l}12.57 \\
(111.3)\end{array}$ & $\begin{array}{c}17.88 \\
(158.4)\end{array}$ & $\left(\begin{array}{c}20.11 \\
(178.1)\end{array}\right.$ & $\begin{array}{r}0.00 \\
0\end{array}$ & 20.11 & $0(00)$ \\
\hline 12市町計 & $\begin{array}{c}5.12 \\
(100.0)\end{array}$ & $\begin{array}{c}6.14 \\
(119.9)\end{array}$ & $\begin{array}{c}7.40 \\
(144.5)\end{array}$ & $\begin{array}{c}8.73 \\
(170.5)\end{array}$ & $\begin{array}{l}16.98 \\
12307\end{array}$ & $\begin{array}{l}25.70 \\
18633\end{array}$ & $66(441)$ \\
\hline
\end{tabular}

注：数值は、事業所統計調查による各年・各市町の事業所数（総数 から農林漁業、捈菜、 建設業、紫造業を除いた数値) 目数とした主要国道治線立地施設数 (表記 $の$ 各年次以 前に開業している施設数を表記の各年次に累算した数倠を分子とした。この数值は現在 営菜中の施設であり、途中廃粱したもの、およひ開策年不明のものが除かれている)の 割合(\%)を示す。

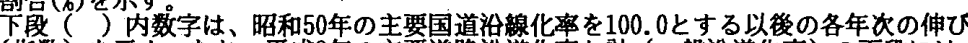

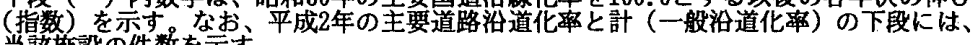

当成2等の主施設道路治道化率は、本文注1)、9)、13)の各条件を算出根拋としている。

\section{3. 沿道化および遠隔化過程}

3.1 沿道化過程の分析

沿道化は，遠隔化とともに主要国道 や主要道路の沿線における施設の立地 現象を表す指標の一つである。と同時 に，この沿道化には主要国道や主要道 路の沿線が「どの程度重視されるか」 という意味も含まれている。立地指向 のつよさを表す指標とも言い換えられ る。

ここでは，まず対象 12 市町におけ る各施設数に対する「主要国道」と「主 要道路」沿線の立地施設の割合 (以下, 「主要国道沿道化率」,「主要道路沿道 化率」と表記し，両者を合算したもの を「一般沿道化率」とよぶ( ${ }^{13)}$ を基に して沿道化の全体動向をつかみ，ひき つづき主要国道別，業種別に沿道化の 特徵を明らかにしていく。

\section{（1）沿道化の進展}

ここでは沿道化の進展を沿道化率と その伸びから考察する。表一2 は，事 業所統計調査の調查年に対応した 4 つ の年次について, 各市町の主要国道浴 道化率とその伸びを示している。さら に, 平成 2 年については, 主要道路に 
ついても作業を行い，主要国道と合わせた一般沿道化率 も明らかにしている。

まず，市町ごとの平成 2 年の主要国道沿道化率をみる と，広島市や海田町などの $7 \%$ 前後の市町から安浦町， 黒瀬町, 安芸津町などの, ほぼ $30 \%$ 以上を占める市町 まで大きな幅がある。

次に，主要道路沿道化率をみる。「主要道路沿道化率」 の平均は $16.98 \%$ と, いまみた「主要国道沿道化率」 (8.73\%)の 2 倍近い比率を占めて高い。とくに高い市 町は本郷町, 安芸津町が $30 \%$ を上回るほか, 東広島市, 黒瀬町などが $25 \%$ を上回る。つづいて広島市, 海田町, 安浦町（各々 $15 \%$ 以上）などで比率が高い。

この「主要道路沿道化率」と「主要国道沿道化率」を 合算した「一般沿道化率」は，すでに明白なように，10 市町が $20 \%$ を越え，このうち $50 \%$ 以上の安芸津町， 黒瀬町, 東広島市を含めて 5 市町が $40 \%$ を上回ってい る。このように,「一般沿道化率」は, 都心商業集積の 高い広島市などにおいても2 割を越えるなど，全体にか なり高い割合になっている。「一般沿道化率」は, 当然, 双方の沿道化率の高さに左右されるが, 人口規模が小さ く，かつ調查道路延長の長い市町ではおおむね高い。逆 に, 広島市や呉市, 調査道路延長の短い坂町, 川尻町, 自然的制約条件のある三原市などでは比率が低くなって いる。

さらには近年における主要国道沿道化率の伸長があ る。昭和 50 年を基準とした各市町の主要国道沿道化率 の伸び（指数）をみると, 元々沿道化率の高かった黒瀬 町 $(29.5 \%$ ・昭和 50 年) を除くと，ほとんどの市町で $150 \%$ 以上という顕著な伸びを示している。なかでも， 安芸津町 (196.3) や安浦町 (184.0), 広島市 (183.7) などの伸びが目立っている。

表一3 営業・休廃業店舗の立地場所別件数

休廃菜数 $/$ 営菜数

\begin{tabular}{|c|c|c|c|}
\hline 国道 & D I D区域内 & D I D区域外 & 計 \\
\hline 2号楾 & $\begin{array}{c}185 / 1746 \\
(82.2) \quad[37.7]\end{array}$ & $\begin{array}{c}71 / 378 \\
(17.8) \quad[55.2]\end{array}$ & $\begin{array}{c}256 / 2124 \\
(100.0) \quad[92.9]\end{array}$ \\
\hline $31 \cdot 185$ 号袙 & $\begin{array}{c}149 / 1394 \\
(70.8) \quad[30.9]\end{array}$ & $\begin{array}{c}104 / 575 \\
(29.2) \quad[58.8]\end{array}$ & $\begin{array}{c}253 / 1969 \\
(100.0) \quad[89.7]\end{array}$ \\
\hline 54量線 & $\begin{array}{c}190 / 2068 \\
(94.2)[16.7]\end{array}$ & $\begin{array}{c}{ }^{2} 17 / 128 \\
{[9.8)^{2}}\end{array}$ & $\begin{array}{c}207 / 2196 \\
(100.0) \quad[26.3]\end{array}$ \\
\hline 375 年線 & \begin{tabular}{c}
\multicolumn{2}{c}{$33 / 238$} \\
$(37.5) \quad[4.7]$
\end{tabular} & $\begin{array}{c}74 / 397 \\
(62.5) \quad[34.6]\end{array}$ & $\begin{array}{l}107 / 635 \\
(100.0) \quad[39.3]\end{array}$ \\
\hline 合 計 & $\begin{array}{l}\text { 557/5446 } \\
(78.7) \quad[90.0]\end{array}$ & $\begin{array}{c}266 / 1478 \\
(21.3)[158.2]\end{array}$ & $\begin{array}{l}823 / 6924 \\
(100.0)[248.2]\end{array}$ \\
\hline
\end{tabular}

注：下段（）内数字は、営業店舗計に対するDID（人口集 中地区）区域内・外別の割合(\%)を示す。［］内の数字 は道路の再離 (kal) を示す。

D I D区域は昭和60年の国勢調查報告による人口集中地区 の区域を各国道におとして卧を测定した。

\section{（2）主要国道別の沿道化の特徵}

4 本の主要国道沿線には, 現在 6924 店が立地・営業 している。4 国道の内 375 号だけが施設数がやや少なく, 他の 3 路線には各々 2000 店前後が立地している。他方, 4 国道を合わせて休廃業 $\left.{ }^{14}\right)$ 施設が約 1 割存在する。営業 と休廃業を合わせた内の休廃業の割合 (休廃業率) は 375 号が最も高い。次いで $31 \cdot 185$ 号であり, 単位道路 長さ $(1 \mathrm{~km})$ 当たりの店舗数（以下, 密度と表記する) が最も多い 54 号で休廃業率は逆に低い。各路線とも休 廃業率はDID 区域内に比べ区域外の方が高い（表一3）。

営業施設の密度は 4 国道を平均すると 27.9 店 $/ \mathrm{km}$ で あるが, 路線ごとに差がある。広島市の都心から北に伸 びる 54 号だけが 79.77 店 $/ \mathrm{km}$ と高く, 他の 3 線はこれ よりかなり低い。東西に伸びる 2 号と $31 \cdot 185$ 号がほぼ 同じ密度で 20 店前後で，375 号はさらに低くなってい る (図一2)。

図-3は，開業施設数が年代ごとによ゙のように変化し てきたかを，国道・業種別に示している。昭和 30 年代 以後, 各路線とも開業施設が漸増し, 60 年以後の開業 が最も多い。60 年以後の割合は, 娛楽遊戯と飲食を中 心に目立ち, 各路線とも $30 \%$ 前後を占める。しかし， 瀬戸内海沿岸を通る $31 \cdot 185$ 号だけは, 30 年代以前の

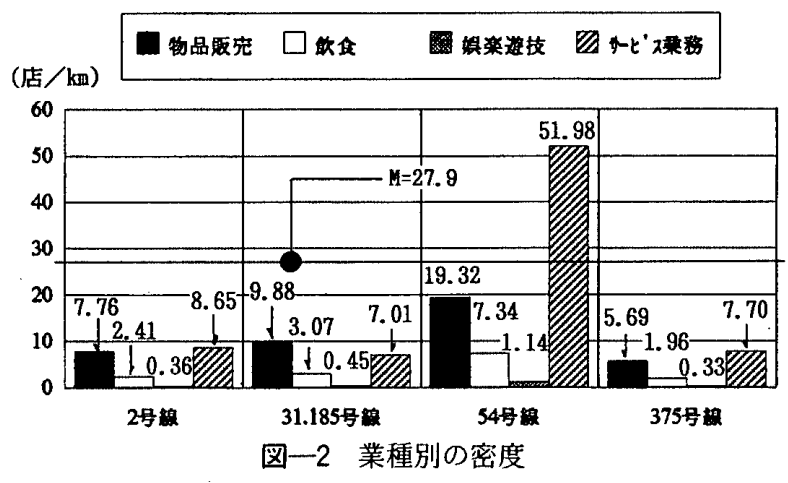

国道54号線

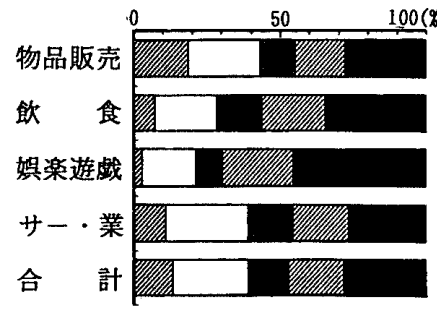

国道31·185号線

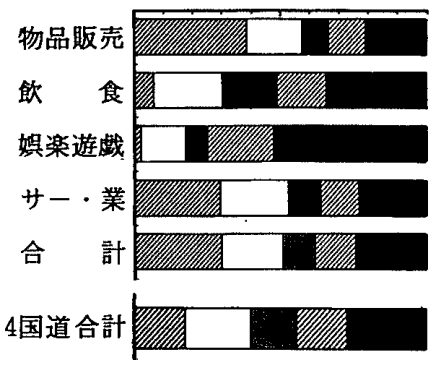

$100(\%)$

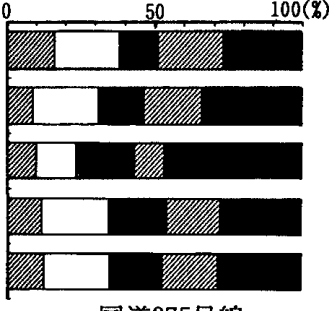

国道375号線

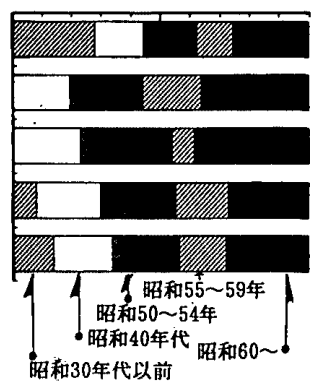

図一3 国道・業種・開業年別施設割合 
旧い開業が約 $30 \%$ と多く，対照 的に 60 年以後の割合 $(24 \%)$ が 少ない。また，施設の絶対量が他 の路線より少ない375 号ではとく に50 年代前半の開業が目立つ。 路線相互に立地の傾向が細かく 違っているが，全体として，国道 沿線への施設の立地量は増大して きている。

各路線とも物品販売とサービ ス・業務の 2 業種の占める割合が 圧倒的に多い。これら両業種とも 31 ・185号では昭和 30 年代まで の旧い開業が目立ち, 他の 3 路線 では 40 年代以降の開業が目立つ。 この内, 54 号は 50 年代の前・後 半の, また, 375 号は 50 年前半 の開業が目立つ。このように東西 に伸びる 2 線に比べ, 南北の 2 線 の方が施設の展開時期が相対的に 遅い。

\section{（3）業種別の沿道化の特徵}

施設が国道の沿線を指向する 「つよさ」は，現在立地している 施設の数 (以下, 立地量と呼ぶ) により，およそ判断できる。つま り，ガソリンスタンドや自動車・バイクなどのような, 立地量がすでに相当ある業種は沿道への立地指向はそれ だけつよい，といえる。しかし，立地量が未だ多くない 業種の中にも最近の増え方が顕著なものがあり，それら は立地指向のつよい業種とみなす必要がある。つまり， 立地指向のつよさには立地量とともに増え方が関係す る。ここでは業種ごとの立地推移に注目した結果, 図一 4 に示す 3 つの型（展開タイプ）を取り出すことができ た。各型の増え方の特徴は次に示すとおりである。すな わち，（）元々かなりの立地量があったため，5つの時 期区分の内, 昭和 40 年代の後半に目立った落ち込みが ある業種，ii）同時期の落ち込みが少なく，その後も目 立った増加のみられない業種，iii）同時期に落ち込みが 全くなく昭和 50 年以降顕著な増加傾向を示す業種，な ビである。

i）の型は，いわゆる在来型沿道化業種と呼ぶべきも ので, ガソリンスタンドや理容・美容, 生鮮以外の食料 品雑貨などの，旧い時期にすでに相当量が沿道に立地し， 近年の展開はあまり大きくない型である。しかし，ガソ リンスタンドに遅れて展開してきた自動車・バイクは, 40 年代後半以後の動向だけをみるときわめて iii）の型 に近いが，立地総量もガンリンスタンドをかなり上回っ ており，この型に含めた。ii）の型に含まれる業種は, ガソリンスタンドなどに次いで旧い時期の立地が一定量 存在し，しかも近年の展開があまり顕著でないものであ る。スーパーや各種物品販売業なよ゙にみられる型である。 以上に比べ，iii）の型は新規沿道化業種と呼ぶべきもの である。この型に含まれる業種は, 喫茶・ファミリーレ ストラン, ラーメン・うどん, などの飲食業をはじめ, 娛楽遊戯のパチンコ・ゲームやごく最近になって急展開 をはじめたカラオケボックスなどもこの型に含まれる。 さらに, 本・レンタルビデオ・CD・スポーツ用品, 紳 士服, 弁当・ファーストフードなどの特定の少品種を扱 う業種に加え，コンビニエンスストアーを合わせた物品 販売がこの型に含まれる。これらの業種の多くは図にも 明らかなように，従来はほとんど国道沿線を指向してい なくて,近年になってから沿道化をはじめた業種である。 3.2 遠隔化過程の分析

ここでは都心からの距離によって施設の立地がいかに 変化してきたかを主にみていく。前半部分で遠隔化の概 要をつかみ, 後半で特定業種の遠隔化の動向を分析する。

（1）遠隔化の全体動向

(1) 主要国道・市町ごとの立地の現況と推移 図一 5

は，遠隔化の動向を総括的に把握するために, 路線ごと 

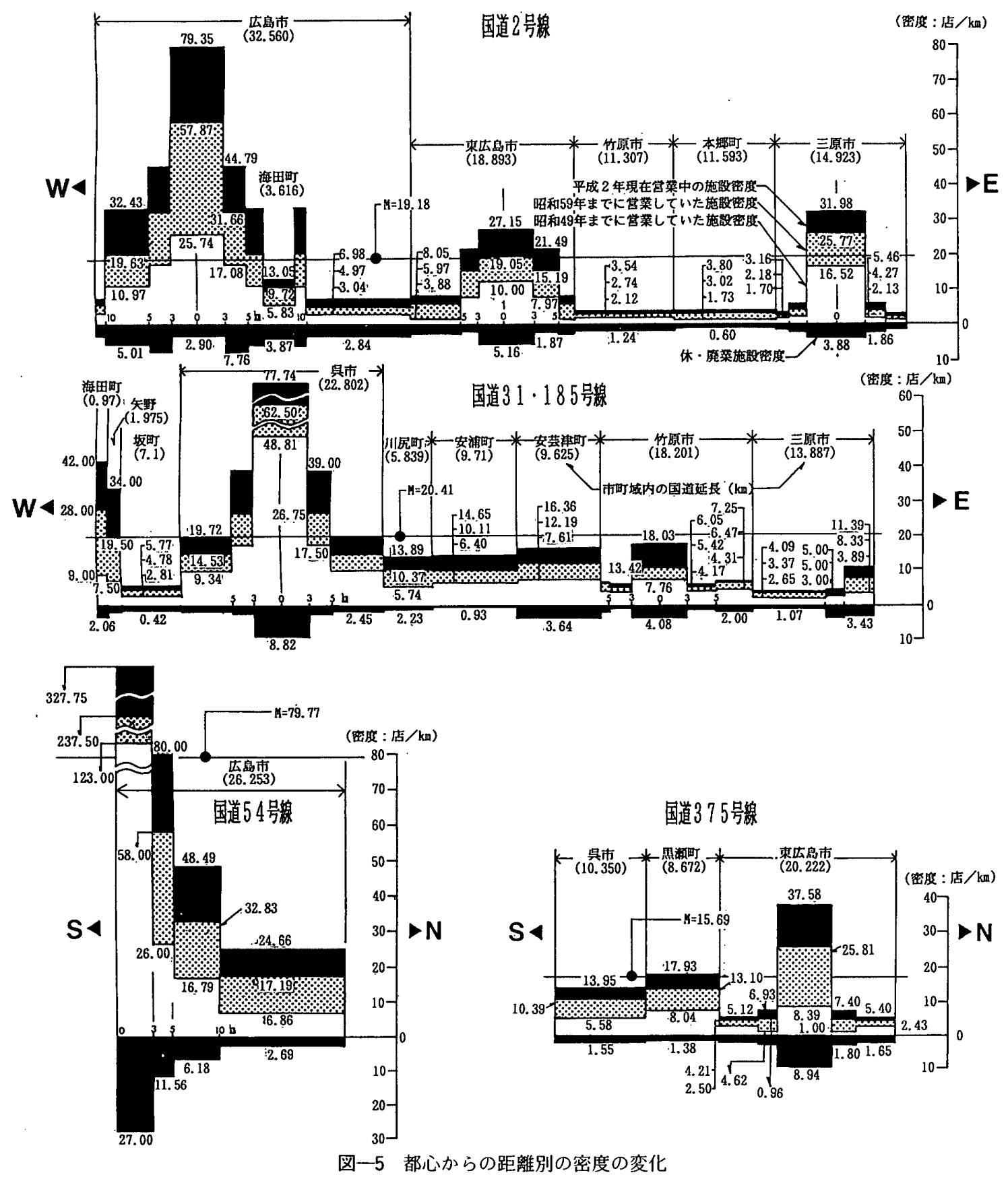

に12の市町をそれぞれ対応する場所に位置づけて密度 とその推移（昭和 50 年と 60 年を境に 3 区分）を示す。

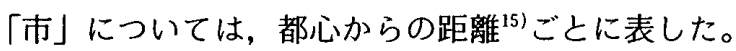

これをみると, 密度は「市」の区域でおしなべて高く， 「町」域で低い。「市」と「町」では密度は格段に異なる。 密度が最も高い国道 (市町・距離帯) は, 54 号 (の広 島市の都心から $3 \mathrm{~km}$ 未満の区域) であり, $1 \mathrm{~km}$ 当たり 300 店を越える。次いで， 2 号の広島市 (同), $31 \cdot 185$ 号の吳市（同）などであるが，ピークの密度は 100 店以 下におちる。しかし, 各路線の密度のピークは何れもこ れら人口規模の大きい都市で, しかも「都心から $3 \mathrm{~km}$ 未満」の距離に存在する。そして,このピークを中心に 都心から離れるにつれ階段状に低下しており，沿道市街 地の拡がりに対応した密度構成になっている。そして,

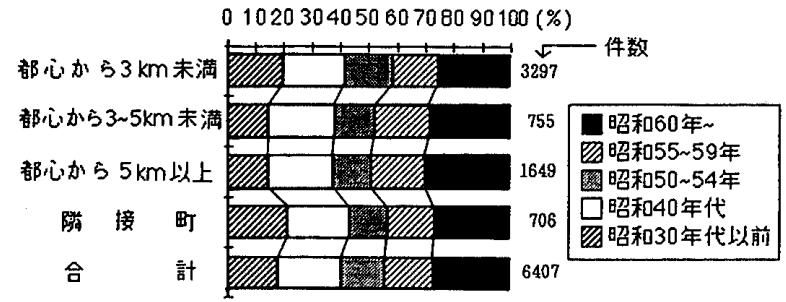

图一6 都心からの距離別の年代別開業割合

密度の増加も,これら大中都市の都心から $3 \mathrm{~km}$ 末満に おいて顕著であり， $3 \mathrm{~km}$ を越える区域での増加は相対 的には小さい。しかし, 昭和 60 年以降は $3 \mathrm{~km}$ 以遠で も著しい。とりわけ 54 号や 2 号の広島市, $31 \cdot 185$ 号 の呉市などにおいてはこの距離帯がかなり目立っている。 他方, こうした大都市部の立地傾向といくぶん異なる 
傾向が中小都市の一部に現われている。2 号の三原市や， $31 \cdot 185$ 号の竹原市， 375 号の東広島市などである。こ れらは広島市などの階段型密度断面に対して, 都心 3 $\mathrm{km}$ 未満の密度だけが高くなった, いわば都心突出型を 示す例である。

(2)．年代別開業動向からみた遠隔化＼cjkstart都心からの距離 ごとに施設（全業種）の開業年代別の割合を示したもの が図一6である。各距離带とも，近年になるほど国道沿 線への立地量が増大し, 昭和 60 年以後の開業が最も多 い。こうした傾向は, 都心 $3 \mathrm{~km}$ 未満に比べその外側の 都心 $3 \sim 5 \mathrm{~km}$ や $5 \mathrm{~km}$ 以上などにおいて，より顕著であ る。先にみたように，国道沿線への施設の立地が全体的 に進んできた現象とならんで，遠隔地への立地も同時に 進行してきている。
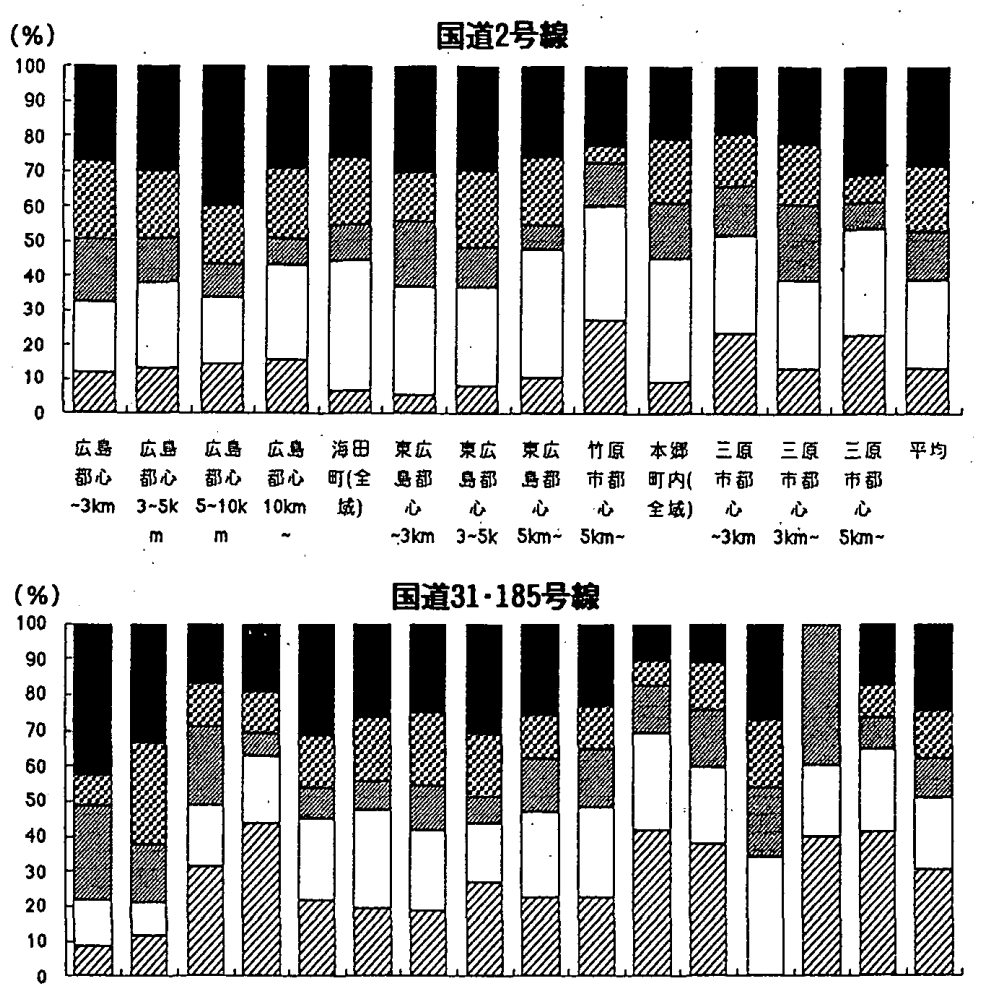

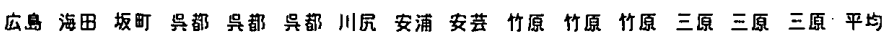

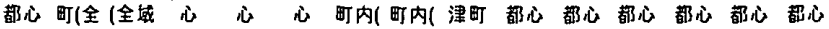

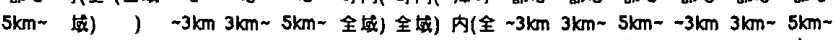
$10 \mathrm{~km} \quad 5 \mathrm{~km}$
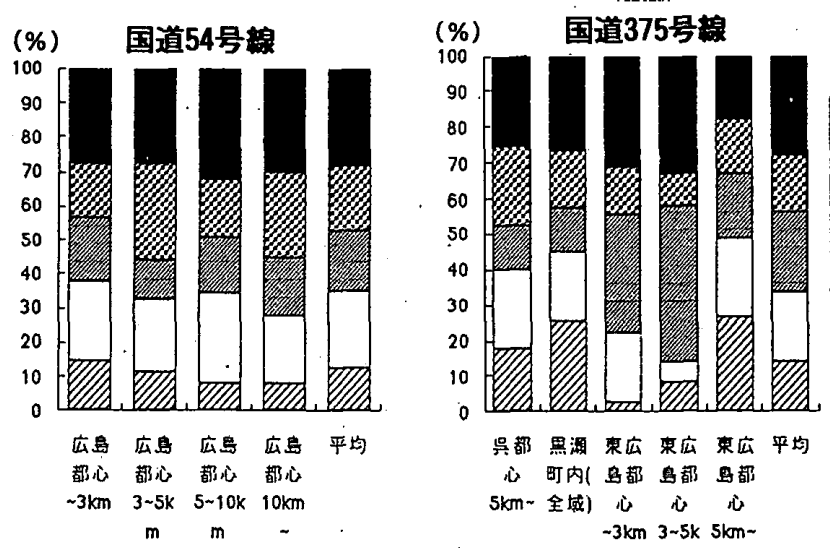

図一7国道・都心からの距離別・年代別開業割合
このような遠隔化の動向をさらに国道・市町ごとに詳 しく見たのが図一7である。各路線とも，各市都心 3 $\mathrm{km}$ 未満の区域よりも，その外側の都心 $3 \sim 5 \mathrm{~km}$ や 5 $\mathrm{km}$ 以上において昭和 60 以後の開業が増えている。と くに広島市 (2 号) では都心 $5 \sim 10 \mathrm{~km}$ で, 遠隔化が顕 著にみられる。2号ではこのほか, 三原市などに類似の 傾向が出ている。東広島市も都心 $3 \mathrm{~km}$ 末満がかなり目 立っているが，やはり，3〜5 km を中心的に增えてきて いる。31・185 号では, 遣市の都心 $3 \mathrm{~km}$ 末満から外側 の3〜5 km の距離帯にかけて遠隔化の傾向が顕著に出 ている。54号は広島市内だけが調査の範囲であるが, この路線では, 昭和 50 年代後半もしくは 60 年以後の割 合が，とくに都心 $3 \mathrm{~km}$ 未満よりも $3 \mathrm{~km}$ を越えた距離, とくに5ー10 km において目立っている。375 号は呉と 東広島の 2 市を通るが都心を通るのは東 広島の方であり, 都心 $3 \mathrm{~km}$ 未満に比べ, 都心 3 $5 \mathrm{~km}$ が若干多くなっている。 広島市の 2 号や 54 号に見られるような 明確な遠隔化の動向は出ていない。

以上のように，広島市のような大都市 では 3〜 $5 \mathrm{~km}$ を越えて, 5 10 km で 60 年以降の遠隔化が顕著である。それに次 いで，地方中心都市の呉市，東広島市 (375 号), 三原市 $(2 \text { 号 })^{16)}$ などでは, 3 5 km での遠隔化が中心である。

（2）業種にみる遠隔化

(1) 4 大業種と特定 5 業種 $の$ 遠隔化 先の沿道化過程の分析では, 近年沿道化 が顕著にみられる新規沿道化業種ともい うべきものを明らかにした。ここでは， そうした業種ほど遠隔化を伴って立地し ているのではないかという仮説のもとに 考察をすすめる。図一8は，4大業種と 一部の典型 5 業種（図の脚注に示すよう に類似のものを加えた 4 業種とガソリン スタンド）について立地変化を詳しくみ たものである。

まず，4大業種からみる。立地量の多 いサービス・業務と物品販売の 2 業種に ついては, 距離的にみた立地推移は, 各 距離帯とも類似した傾向を示しており， 遠隔化の傾向はみられない。それらに比 へ，飲食や娱楽遊戯については, 都心 5 $\mathrm{km}$ 以上と隣接町においてとくに 60 年 以降の増加が目立 5, 遠隔化の㑯向か顕 著である。

次に, 近年沿道化の著しい典型業種と して採り上げたコンビニエンスストア， 
パチンコ，本，ファミリーレストランな ビの 4 業種についてみる。このうち, パ チンコや本などは，都心から隣接町まで 地域を問わず立地が急增しているが，コ ンビニエンスストアなど，ファミリーレ ストランなどは遠隔化を示している。

在来型沿道化業種の典型として示した ガソリンスタンドは, 物品販売やサービ ス・業務などと類似の立地変化を示すが 遠隔化の傾向はさらに小さくなってい る。

(2) 主要国道・市町ごとの特定業種の遠 隔化 図一9は，近年の開業率がとく に高い業種（昭和 60 年以後の開業割合 が全立地数に対して $30 \% ， 50 \%$ 以上を 占めるもの）を採り上げて，路線ごとに 立地割合を見たものである。全業種につ いては，各国道とも各市の都心 $3 \mathrm{~km}$ 未 満の割合が圧倒的に高い。しかし，近年 の開業率が高い業種をみると，明らかに 都心 $3 \mathrm{~km}$ 末満よりも $3 \mathrm{~km}$ 以遠の距離 に多く立地する傾向が出ている。とくに， 2 号, 54 号の広島市の $5 \sim 10 \mathrm{~km}$ におい てこのような動向が顕著であり，近年の 開業率が高い業種ほど都心 $3 \mathrm{~km}$ 未満よ り外側の $3 \mathrm{~km}$ 以遠での立地が明確に進 行している。

\section{4. 立地変化と施設の運営内容}

3 章で施設の立地変化をみた。本章で はサンプリング調査の結果をもとに店埔 の運営内容を表す店舗規模と駐車場規模 および営業時間と休日日数の 4 項目につ いて, 都心功の距離・開業年との関係 を軸に分析をすすめ, 店舗の内的条件が 立地場所と関連をもちながら変化してい ることを明らかにする。

\section{（1）店舗規模と駐車場規模}

店舗の売場面積は最小の $4 \mathrm{~m}^{2}$ から $19000 \mathrm{~m}^{2}$ まで大きくバラッイている。 平均すると $635 \mathrm{~m}^{2}$ となる (今回, 建物 の中を売場としたため, 屋外部分が売場 として重要な役割をもつガソリンスタン ドや自動車・バイクなどの売場面積は実 態よりかなり小さい。このため，これら を除く物品販売と飲食を合わせた計 237 件についてみた平均がこの数值である)。 ガソリンスタンドなどを含めて計算する
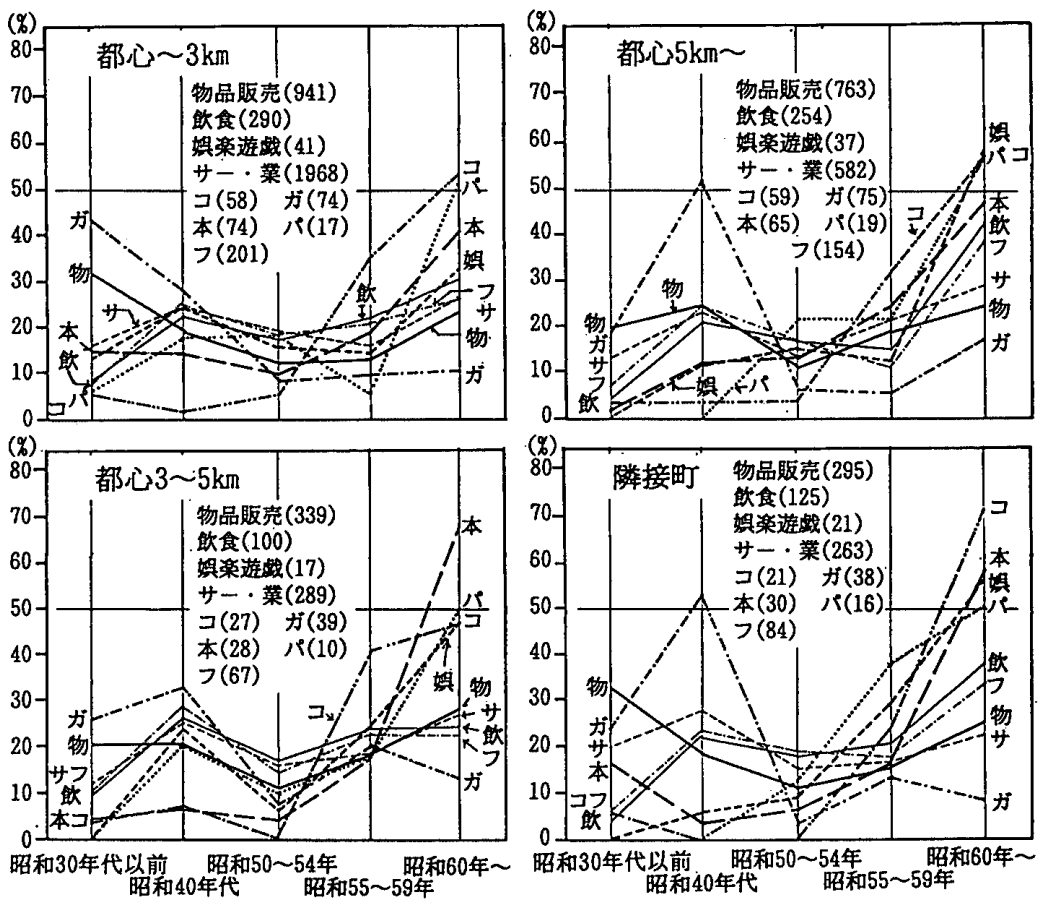

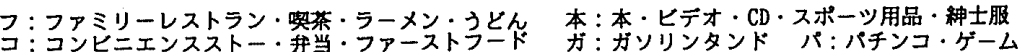
図一8 都心からの距離別・業種・年代別開業割合
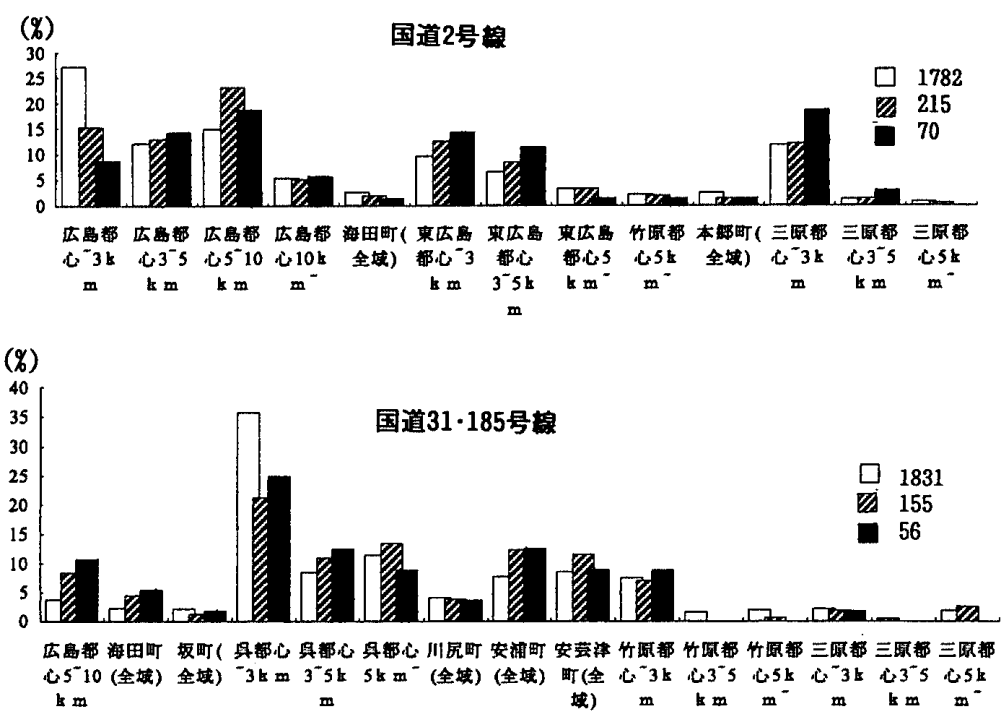

(\%)

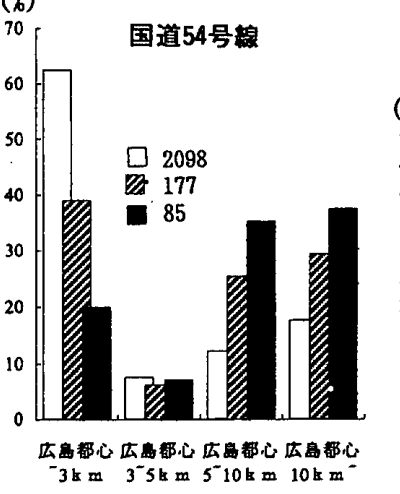

国道375号幏

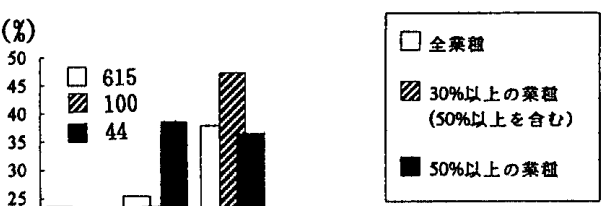

注 : 图中の数字は件 (店) 数
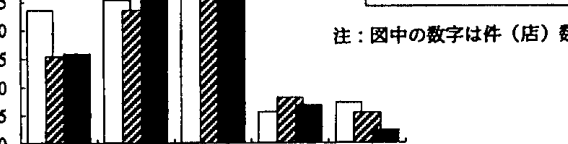

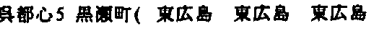

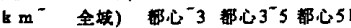

t $m$ is m m

図一9 全業種および昭和 60 年以後の開業割合が多い（30\%， $50 \%$ 以上を占める）業種の立地場所別割合 
と, $705 \mathrm{~m}^{2}$ といくぶん大きくなるが，屋外を売場に含 めた奉態はさらに大きくなると思われる。規模をいくつ かのランクに分けて店舗の分布をみると, 最も多いのが 200 $500 \mathrm{~m}^{2}$ (108店，32\%）である。これを中心に $100 \mathrm{~m}^{2}$ 未満や 100 $200 \mathrm{~m}^{2}$ 未満の小さい方にやや偏って いるが; 最も大きい $1000 \mathrm{~m}^{2}$. 以上のランクにも $13 \%$ (43 件) が分布する。こうした全体的規模分布の中で, 都心に隣接した都心 $3 \sim 5 \mathrm{~km}$ における $500 \sim 1000 \mathrm{~m}^{2}$ の 規模 $(21 \%)$, 隣接町内における $1000 \mathrm{~m}^{2}$ 以上の割 合 $(23 \%)$ が目立っており, 都心 $3 \mathrm{~km}$ 末満における売 場の規模別分布と比較してこうした遠隔地での規模が相 対的に大きくなっている(表一4)。

次に，駐車場規模についてみる。表一4（下段）は「駐 車場なし」から「1000 $\mathrm{m}^{2}$ 以上」までの 5 つのランクに 分けて都心からの距離帯別に分布をみている。上記の売 場の広さ分布にみられた傾向, つまり, 都心 $3 \mathrm{~km}$ 末満 で小規模店舗が多く, 遠隔地で大規模店舗が相対的に多 くなる傾向は, 駐車場の規模分布にも同様にみられる。 この傾向は，「駐車場なし」の割合でみるとより明確と なる。すなわち, 都心 $3 \mathrm{~km}$ 末満では「駐車場なし」が $30 \%$ を占めるが，3〜5 km， $5 \mathrm{~km}$ 以上では $10 \%$ 程度， 隣接町では $5 \%$ と少なくなっている。駐車場をもつ店 舗は,これとは逆の傾向をみせる。駐車場についても， 遠隔地，とくに隣接町を中心に大規模な事例为増える傾 向がつよい。

立地場所別に, 店舖の規模, 駐車場の保有率 - 規模に ついて，個別にみてきたが，これら両者の関係をみたも のが表一5である。売場面積が $1000 \mathrm{~m}^{2}$ 以上になると, すべての店舗（22）が駐車場を保有するなど, 店舗規模

表-4 都心距離別の売場面積と客用駐車場面積

\begin{tabular}{|c|c|c|c|c|c|c|}
\hline & & 檠㳻 $^{3 \mathrm{~km}}$ & 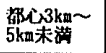 & $\begin{array}{l}\text { 都心5k血以 } \\
\text { 上 }\end{array}$ & 澵町内 & 合 渮 \\
\hline \multirow[t]{2}{*}{$\begin{array}{l}\text { 党 } \\
\text { 面 } \\
\text { 积 }\end{array}$} & 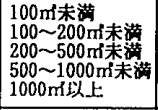 & $\begin{array}{l}25(20.2) \\
25(19.4) \\
39(30.2) \\
21(16.3) \\
14(10.3)\end{array}$ & $\begin{array}{c}21(25.6) \\
14(16.9) \\
23(27.7 \\
17(20.5) \\
7(8.4)\end{array}$ & $\begin{array}{l}16(16.5) \\
16(16.5 \\
34(35.1) \\
18(18.6 \\
13(13.4)\end{array}$ & $\begin{array}{r}8(20.0) \\
8(20.0) \\
12(30.0) \\
3(7.5) \\
9(22.5)\end{array}$ & $\begin{array}{r}70(20.4) \\
63(18.4) \\
108(31.5) \\
59(17.2) \\
43(12.5)\end{array}$ \\
\hline & 計。 & $124(100.0)$ & $82(100.0)$ & $97(100.0)$ & $40(100.0)$ & $343(100.0)$ \\
\hline \multirow[t]{2}{*}{ 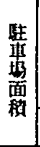 } & 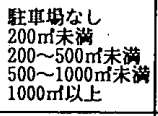 & $\begin{array}{r}37(29.8) \\
27(21.8) \\
19(15.3) \\
9(7.3) \\
32(25.8) \\
\end{array}$ & $\begin{array}{r}7(8.9) \\
-35(44.3) \\
18(22.8) \\
10\} 12.7\} \\
9(11.4) \\
\end{array}$ & $\begin{array}{l}10(10.2) \\
29(29.6 \\
27(27.6 \\
14(14.3 \\
18(18.4) \\
\end{array}$ & \begin{tabular}{|c|}
$2(5.1)$ \\
$5(12.8)$ \\
$10(25.6)$ \\
$88(20.5)$ \\
$14(35.9)$ \\
\end{tabular} & $\begin{array}{l}56(16.5) \\
96(28.2) \\
74(21.8) \\
411(12.1) \\
73(21.5) \\
\end{array}$ \\
\hline & 計 & $124(100.0)$ & $79(100.0)$ & $98(100.0)$ & $39(100.0)$ & $340(100.0)$ \\
\hline
\end{tabular}

表一5 売場面積と駐車場面積

\begin{tabular}{|c|c|c|c|c|c|c|c|}
\hline 売場面糟 䑶車場 & 學車城 & \begin{tabular}{|l}
$2000 \mathrm{n}$ 未 \\
满
\end{tabular} & $\begin{array}{l}200 \sim 500 \\
\mathrm{~m}^{\prime} \text { 末满 }\end{array}$ & $\begin{array}{l}500 \sim 100 \\
0 \text { m未满 }\end{array}$ & $1000 \sim 20$ & $2000 \mathrm{~m}$ & 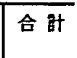 \\
\hline 100 m末未渆 & 13 & 33 & ${ }^{7}$ & 2 & 3 & 17 & 59 \\
\hline 100m 200m末浒 & $(22.0)$ & $(55.9)$ & $(11.9)$ & $\begin{array}{l}(3.4) \\
9\end{array}$ & (5.1) & $(2.7)$ & $(100.0)$ \\
\hline $200 \mathrm{mi} \sim 500 \mathrm{~m}$ 未满 & $\begin{array}{r}(25.5) \\
4\end{array}$ & (27i & (25.5) & $\begin{array}{l}(16.4) \\
19\end{array}$ & $(1.8)$ & $(3.6)$ & $(100.0)$ \\
\hline $500 \mathrm{~m} \sim 1000 \mathrm{~m}$ 末満 & (5.3) & $(14.7)$ & $\begin{array}{l}(24.0) \\
3\end{array}$ & $(25.3)$ & (21.3) & $(9.3)$ & $\begin{array}{c}(100.0) \\
25\end{array}$ \\
\hline $1000 \mathrm{~m}$ 以上 & & $(12.0)$ & $\begin{array}{r}(12.0) \\
2 \\
(9.1)\end{array}$ & $\begin{array}{l}(8.0) \\
2 \\
(9.1)\end{array}$ & $\begin{array}{c}(48.0) \\
4 \\
(18.2)\end{array}$ & $\begin{array}{l}(16.0) \\
14 \\
(63.6)\end{array}$ & $\left(\begin{array}{l}(100.0) \\
22 \\
(100.0)\end{array}\right.$ \\
\hline 㝇 & $(13.6)$ & $\begin{array}{c}62 \\
(26.3)\end{array}$ & $\begin{array}{c}44 \\
(18.6)\end{array}$ & $\begin{array}{c}34 \\
(14.4)\end{array}$ & $(15.3)$ & $\stackrel{28}{(11.9)}$ & $\left(\begin{array}{c}236 \\
(100.0)\end{array}\right.$ \\
\hline
\end{tabular}

の拡大につれて駐車場の保有率もほぼ上昇し，規模も拡 大している。

\section{（2）日営業時間と年間休日日数}

一日のうちで開店と閉店のシステムをとる「定時営業 型」の店舗が 9 割以上を占め,「24 時間営業」の店赤は 約 $6 \%$ にとどまる。しかし, 営業時間の長さをみると, 10 時間以上が約 7 割（24 時間営業を合わせ）を占め, さらに 12 時間以上だけでも 3 割を上回わる。長時間営 業の店舗が全体的に多い。他方, 12 時間以上の店舗 (123 店) の内, 約 $2 / 3$. (83 店) が最近 10 年以内に開 業しており, 24 時間営業店舗の近年の増加と合わせ, 営業時間の伸長傾向が目立ってきた。こうした長時間化 傾向は，大きな差ではないが「隣接町」に比べ「市」域 における3つの距離帯においてよりつよい。

休日日数は, 年間で 9 日間以下の店舗が $1 / 4$ 強を占め 最も多く，年中無休の店舗 $(16 \%)$ を合わせると 4 割 以上が休日の少ない営業形態をとっている。年中無休に ついては, とくに都心 $3 \mathrm{~km}$ 末満の距離帯で約 2 割を占 めて目立ち, 都心から遠隔化するにつれ順次この割合が 減少し，隣接町内で最も少なくなっている。このように， 一日の中での営業時間の伸長, に加えて, 休日数の诚少 傾向が並行してすすんでいる（表一6）。

\section{5. まとめ}

主要国道と主要道路沿線における施設の立地変化をも とに沿道化, 遠隔化の現象をとらえ, 合わせて店舗の営 業内容をみた。分析でえられた知見を列挙し，最後に本 論文で着目した諸現象について考え方を総括したい。

(1) 主要国道沿道化率は, 約 $8.7 \%$ (平成 2 年の 12 市 町平均) であり，主要道路沿道化率（約 $17.0 \%$ ）の約 $1 / 2$ である。両者を合わせた一般沿道化率は $26 \%$ とな る。一般沿道化率は，50\%を越える安芸津町, 黒瀬町, 東広島市を含めて 5 市町で $40 \%$ を上回る。この主要国 道沿道化率は，ほとんぼの市町が最近 15 年の間に 1.5 倍程度に伸びており, 主要国道における沿道化の進展を 示した。

沿道化の進展は，業種（業態）により異なる。進展過 程から 3 つの型に分けられ, 最も沿道化のつよい型とし

表一6 都心距離別の日営業時間と年間休日数

\begin{tabular}{|c|c|c|c|c|c|c|}
\hline & & 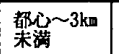 & 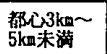 & 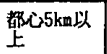 & 智接町内 & 合 斯 \\
\hline \multirow[t]{2}{*}{$\begin{array}{l}\text { 最 } \\
\text { 暴 } \\
\text { 成 }\end{array}$} & 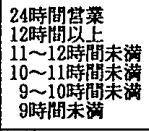 & $\begin{array}{c}6(4.7) \\
46(35.9) \\
13(10.2) \\
24(18.8) \\
31(24.2) \\
8(6.3) \\
\end{array}$ & $\begin{array}{c}9(11.0) \\
26631.7 \\
16(19.5 \\
1720.5 \\
11(13.4) \\
3(3.7) \\
\end{array}$ & $\begin{array}{c}4(4.1) \\
38(38.8) \\
7(7.1) \\
22(22.4) \\
20(20.4) \\
7(7.1) \\
\end{array}$ & $\begin{array}{c}1(2.5) \\
14(35.0) \\
7(17.5) \\
7(17.5) \\
11(27.5)\end{array}$ & $\begin{array}{c}20(5.7) \\
124(35.6) \\
43(12.4) \\
70(20.1) \\
73(21: 0) \\
18(5.2) \\
\end{array}$ \\
\hline & 小 尌 & $128(100.0)$ & $82(100.0)$ & $98(100.0)$ & $40(100.0)$ & $348(100.0)$ \\
\hline \multirow[t]{2}{*}{$\begin{array}{l}\text { 复 } \\
\text { 留 } \\
\text { 量 }\end{array}$} & 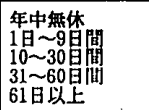 & $\begin{array}{l}25(20.3) \\
31(25.2 \\
3125.2 \\
2520.3 \\
11(8.9)\end{array}$ & $\begin{array}{r}14(17.3) \\
25(30.9) \\
8(9.9) \\
24(29.6) \\
10(12.3)\end{array}$ & $\begin{array}{l}14(14.6) \\
25(26.0 \\
2020.8 \\
2324.0 \\
14(14.6)\end{array}$ & $\begin{array}{c}3(7.5 .5) \\
13(32.5) \\
133(32.5) \\
922.5) \\
2(5.0)\end{array}$ & $\begin{array}{l}56(16.5) \\
9427.6) \\
722121.2 \\
8123.8 \\
37(10.9)\end{array}$ \\
\hline & 斯 & \begin{tabular}{|l|}
$123(100.0)$ \\
\end{tabular} & $81(100.0)$ & $96(100.0)$ & $40(100.0)$ & $340(100.0)$ \\
\hline
\end{tabular}


て約 10 業種がある。この内コンビニエンスストアー, 弁当・ファーストフード，カラオケボックスなどは典型 的沿道化業種で, 多くがチェーン化を伴う。これら沿道 化の著しい業種の内，本や喫茶などは，従来は，主要国 道以外の場所にかなり立地してきたもので，元々沿道を 指向してはいない。つまり，急激に沿道化している業種 の中にも，途中から新たに沿道化し始めたという，立地 の方向転換を図ったものがある。

(2) 主要国道浻線における施設の密度構成は，広島市や 呉市などの大中都市においては, 都心 $3 \mathrm{~km}$ 末満をピー クに, 3〜 $5 \mathrm{~km}, 5 \mathrm{~km}$ 以上と距離が増大するにつれて密 度が低減する階段型になっている。密度の増加は，都心 $3 \mathrm{~km}$ 末満を中心に長期間進行してきたのであるが, 近 年における $3 \mathrm{~km}$ 以上や $5 \mathrm{~km}$ 以上の遠隔地での増加は, かなり目立つ。他方， 2 号の三原市や 375 号の東広島市 などは, 都心 $3 \mathrm{~km}$ 末満の密度だけが突出した形を見せ ている。このように，沿道の密度の高さや形状を規定す るのは，基本的には都市（人口）規模と考えられるが， それに加えて立地を妨げる自然的条件等も密度を規定す る要因になっている。

(3) 近年の施設の立地は, 都心 $3 \mathrm{~km}$ 末満に加え，その 外側の $3 \mathrm{~km}$ 以上や $5 \mathrm{~km}$ 以上，さらに町域においても目 立っている。遠隔化は総体としてすすんだが，その㑯向 は業種（業態）ごとに差異がある。とくに，ファミリー レストランやコンビニエンスストアーなどの, 近年に なって急激に沿道化してきた業種は，同時に遠隔化の傾 向も顕著に示す。

(4) 沿道化や遠隔化をつづけている店舗は，それ自身で 集積条件をつくる必要がある。24 時間営業を含め, 営 業時間の延長や休日数の縮小など，店舗は時間的な面か ら消費者との接触の増大を図っている。その一方で，駐 車場の確保・規模拡大をすすめるなど，車利用客という 特定の消費者をさらに重視する方向でも店舗は対応して きている。

本論文で明らかにしてきた沿道化，沿道遠隔化過程な らびにそれに対する考え方をここで総括的に示す。

商業施設の沿道立地は従来，ガソリンスタンド，自動 車関連施設などに限られていた。昭和 50 年頃から各種 の業種が沿道立地を進め, 60 年以降になると, それま で都心型だった業種までが沿道化しはじめ,より遠隔化， 大型化してきた。これは, 沿道化の新たな質的展開過程 としてとらえられる。その中には，大規模書店に典型的 にみられるように，店舗が単独で集積・集客の魅力を高 めるため，数十店舗分に相当する規模をもち，あるいは その都市で最大規模の店舗が都心に存在しないといった 事態も生じることとなる。さらに, 現在, 都心商業集積 のシンボル的存在であるデパートなどが沿道立地化する 可能性も考えられる。こうしたことは，都心部での商業
施設の娍少衰退を伴う大幅な商業構造の変動である。沿 道化が車利用層のための施設立地だけの段階では問題は 相対的には小さい。しかし，都市・居住者によっての生 活不可欠施設や最も中心となる商業施設, 大規模施設等 が車利用層しか利用しにくくなれば大きな問題である。 商業施設の分散化傾向はこうした大きい問題をはらんで いるといえるだろう。

\section{注・参考文献}

1）本論文では，市街地を構成する主な道路を「主要国道」 と「主要道路」の 2 種類に分けて，沿道化などの考察を すすめた。調查対象 12 市町の中心を通る 4 本の国道を「主 要国道」として定義し，他方「主要道路」には，これら 4 本の国道以外の国道のほか, 「県道」の内, 主な道路と みなされるもの，および県道と連続することによって一 本の主要な道路を構成する「市道」などを含めた。

2）広辞苑（第 4 版）によると，郊外とは「市街地に隣接し た地域。まちはすれ」となる。本論においても同様の意 味に理解している。しかし，この「郊外」は，面的に拡がっ た状態を指しており，本論のように，主要国道ないし主 要道路に限定して施設の立地を検討した場合には, 適切 な表現とはならない。そのため，本論では，郊外への施 設の移動を意味する「郊外化」という用語のかわりに「沿 道遠隔化」(場合によっては「遠隔化」と略称）の用語を 使い，必要不可欠な場合を除き「郊外」を使用していない。 なお，遠隔化の分析を行うために，以下のように細か く距離带を設けた。すなわち, 調査対象の 5 市 7 町を通 る 4 本の国道に対し，5市については各中心（市役所の 位置を仮の中心とした）から $3 \mathrm{~km}$ 未満の区域（中心か ら直線距離で国道におとした $3 \mathrm{~km}$ 未満の距離の範囲) をとり,これを中心に，両側に $3 \mathrm{~km} \sim 5 \mathrm{~km}$ 末萭, $5 \mathrm{~km}$ 以上 (広島市を除く 4 市につて)，5 km $10 \mathrm{~km}$ 末満 (広 島市のみ), $10 \mathrm{~km}$ 以上（広島市のみ）などの距離をとっ た。「町」の区域は距離帯を設けず「町域」として一括し た。そのため, 本論において「遠隔地」とは,「市」の中 心から $3 \mathrm{~km}$ 末満の区域を基点にして，その外側に位置 する区域を指している。しかしこうした見方のほかに広 島市の中心」を「都心」とみ，他の 11 市町全域を「遠隔 地」とみなすこともできる。つまり，この「遠隔地」は， 相対的な位置関係をつよく表わす用語である。

3）前揭 注 2)にも示すが，「都心」には，面的な拡がりに 対する中心という意味がある。ここではこの本来の意味 で用いている。しかし, 本稿では, 主要国道や主要道路 を対象に，いわば「線」上における施設の立地現象を扱っ ているので，この一般的な意味の「都心」とは異なる用 法になっている。なお，小規模な「市」や「町」などに ついては都心」と呼称することが適切でない場合も多い。 この点を考慮して「中心」または「中心部」等の類似の 用語を使った場合もある。

4）都市の中心・内環部の変容や衰退化の問題については, 今回採り上げて検討していないが, 今後考察をすすめて いく予定にしている。

5）「交通弱者」の定義については，交通権学会編「交通権」 日本経済評論社, 1986.10, 上田 篤「くるまは弱者のも の」中公新書, 1979.10などに詳しい。なお，木村一裕・ 
清水浩志郎らは「身体障害者の外出特性に関する基礎的 考察」(都市計画論文集 NO. 25，1990，pp.67〜72)の 中で，高秢者，身体障害者のほか，けがなどによる一時 的移動制約者も含め「移動制約者」とし，その交通環境 問題を取り扱っているが, 本論にいう交通弱者とは，そ れらの人たちも視野に含めている。

6）（社）日本不動産協会近畿会：「郊外ロードサイド店舗進 出と地価」学芸出版社, 1990.3

7）石黒哲郎，小坂 宏：沿道土地利用の変動に関する研究 一東京都区部西郊地区におけるケーススタディその 1 , その 2 , その 3 , 日本建築学会大会学術講演梗概集 F, 1988, 1989, 1990

8） 31 号と 185 号は吳市内で分かれているが，合わせて一本 の国道として取り扱った。

9)「主要道路」として選定した市町ごとの路線数, 距離は, 広島市 $(17,116 \mathrm{~km})$, 遣市 $(8,66 \mathrm{~km})$, 竹原市 $(6,34 \mathrm{~km})$, 三原市 $(3,28 \mathrm{~km})$, 東広島市 $(14,116 \mathrm{~km})$, 海田町 (3, $3 \mathrm{~km})$, 黒瀬町 $(4,22 \mathrm{~km})$, 本郷町 $(5,31 \mathrm{~km})$, 安芸 津町 $(4,17 \mathrm{~km}$ ), 安浦町 $(2,8 \mathrm{~km}$ ), の 10 市町 (合計 66 , $441 \mathrm{~km}$ ) である。坂町と川尻町は非設定。

10）本文の冒頭に「商業・業務施設」として示しているが, 本調査では，銀行や事務所等の業務系の施設も大きく商 業施設の中に含めて取り扱った。調查の対象から除いた 施設は，工業系施設と専用住宅施設だけである。なお調 查は住宅地図に記載されている施設をベースにしたが, 現地で新たにみつかった施設は対象に含めた。

11）営業している6924 件のうち物販 (2476), 飲食 (848), 娛楽遊戯（136），およびサービス・業務の内の理容・美 容 (273)，クリーニング (86), モーテル・旅館等 $(47)$, などを合わせた 3866 件を母数とし，これの $20 \%(773)$ を調查対象とした。
12） 1990 年国勢調査報告については，広島県による速報 (1990 年 12 月 7 日付け朝日新聞に公表されたもの) を 使用。

13）「主要国道沿道化率」，「主要道路沿道化率」および両者を 合算した「一般沿道化率」を表一2に示す。沿道化率の 算出基準を同表の脚注に示した。なお，「主要道路沿道化 率」は，下記の住宅地図（対象地区・発行年月）による 件数をもとに算定している。すなわち「記載内容の実態は, 収録版によっても異なるが平均して出版年月の半年程度 以前である」(ゼンリン出版) ので, 表一 2 の平成 2 年の 「主要道路沿道化率」は，広島市を中心にしてほぼ，平 成 3 年時点の「率」を表している。広島市中区・西区版 ('92.1), 同東・南区版 ('92.1), 同安芸地区版 ('92.4), 同安佐北区版 ('92.6), 東広島市版 ('92.2), 三原市版 ('92,3), 竹原市版 ('90.12), 吳市版 ('92.9), 安浦地 区電話帳付録（各戸記載図, '91.10 と吳市版'89.1) 等で ある。

14）最新版住宅地図に記載されている施設名称をベースとし て現地観察を行い, 存在していなかったものを廃業, 存 在して休業中とみなされるものを休業施設とした。

15）前揭 注2)にもふれているが，本調查では対象とした 5 市について当該市役所の位置を仮の都心に設定し，そ こを中心に, $3 \mathrm{~km}, 5 \mathrm{~km}, 10 \mathrm{~km}$ の直線距離を各国道に 落として区分している。なお, 密度を算出するための距 離は，各国道に落とした位置までの距離を，道路(の曲線) に沿ってキルビメーターで測定した長さである。

16）三原市の場合は，3～ $5 \mathrm{~km}$ の自然条件などの制約が大き く，立地が抑えられたために，5 km 以上の距離で偶然的 に遠隔化が目立っているものと考えられる。

(1992 年 7 月 10 日原稿受理, 1993 年 1 月 19 日採用決定) 